\title{
GEOSPATIAL DATA FOR COMPUTERISATION OF PUBLIC ADMINISTRATION IN THE CZECH REPUBLIC
}

\author{
V. Cada. T. Mildorf \\ University of West Bohemia, Pilsen, Czech Republic (cada, mildorf)@kma.zcu.cz \\ Commission IV, WG 8
}

KEY WORDS: Spatial Infrastructures, Digitisation, Planning, Database, Framework Data

\begin{abstract}
:
The main aim of the eGovernment programme in the Czech Republic is to enhance the efficiency of public administration. The Digital Map of Public Administration (DMVS) should be composed of digital orthophotographs of the Czech Republic, digital and digitised cadastral maps, digital purpose cadastral map (ÚKM) and a technical map of municipality, if available. The DMVS project is a part of computerisation of public administration in the Czech Republic. The project enhances the productivity of government administration and also simplifies the processes between citizens and public administration. The DMVS project, that should be compliant with the INSPIRE (Infrastructure for Spatial Information in the European Community) initiative, generates definite demand for geodata on the level of detail of land data model. The user needs that are clearly specified and required are not met due to inconsistencies in terminology, data management and level of detail.
\end{abstract}

\section{INTRODUCTION}

The exploitation of information and communication technologies (ICT) for computerisation of public administration should simplify the communication of citizens and private sector with governmental bodies. Computerisation of public administration is an essential pre-requisite for functionality and development of public administration aiming at optimisation of internal processes. Public administration includes publication of administrative acts on the basis of decision making processes. This cannot happen without up-to-date source data. Implementation of the eGovernment programme necessarily need creation and maintenance of infrastructure for basic register data processing and other applications.

The main aim of the eGovernment programme should be to enhance the efficiency of public administration. It should simplify the activities of public in relation to public administration and vice versa. A standardisation of governmental processes is the way how to achieve it. Standards can support optimal exchange of information.

Computerisation of public administration is limited by quality, up-to-date and reliable geodata. Geodata (geospatial data) are locating data that ensure integration of thematic and application databases. Basic geodata have an integration character and create a common basis for majority of thematic or application databases. Basic geodata ensure to location of basic features, they are application independent and enable integration of data from various sources. A common characteristic of these data should be the accuracy and level of detail equivalent to mapping of parcels in large scales (land parcel data model) and not only topographic maps in middle scales. Land parcel data model includes a set of geographic features representing objects from the real world with a minimal level of generalisation. The basic entity is a land parcel representing a piece of land on the Earth's surface. An essential part of the infrastructure for basic spatial data at land parcel data model level and its maintenance is a digital cadastral map. The content of the digital cadastral map is a part of the file of geodetic information and is delimited by Act. No. 344/1992 Coll., on Cadastre of Real Estates of the Czech Republic (Cadastral Law) and by Decree No.26/2007 Coll. of the Czech Office for Surveying, Mapping and Cadastre performing the Act No.265/1992 Coll., on Registration of Proprietary and other Material Rights to Real Estates in wording of later regulations and the Act No. 344/1992 Coll., on Cadastre of Real Estates of the Czech Republic (Cadastral Law) in wording of later regulations.

Geographic feature is defined by International Organisation for Standardization (2004) as a representation of real world phenomenon associated with a location relative to the Earth. Some items of the content of digital cadastral map can be perceived as geographic features. Some items do not comply with the definition of geographic feature and its name has to be modified, e.g. municipal border is perceived as municipal territory. The other geographic features can be generated as a combination of several items of the content of digital cadastral map, e.g. the intersection of building parcel and inner line in the parcel creates a geographic feature building. Figure 1 shows several examples of the content of digital cadastral map and associated geographic features. Further details can be found in (Cada V. \& Mildorf T. 2005).

The Infrastructure for Spatial Information in the European Community (hereinafter referred to as INSPIRE) initiative intensively specifies basic geodata - reference data and core thematic data. INSPIRE was established by the Directive 2007/2/EC of the European Parliament and of the Council of $14^{\text {th }}$ March 2007 (hereinafter referred to as INSPIRE Directive). INSPIRE lays down general rules to establish an infrastructure for spatial information in Europe for the purposes of Community environmental policies, and policies or activities which may have an impact on the environment. 


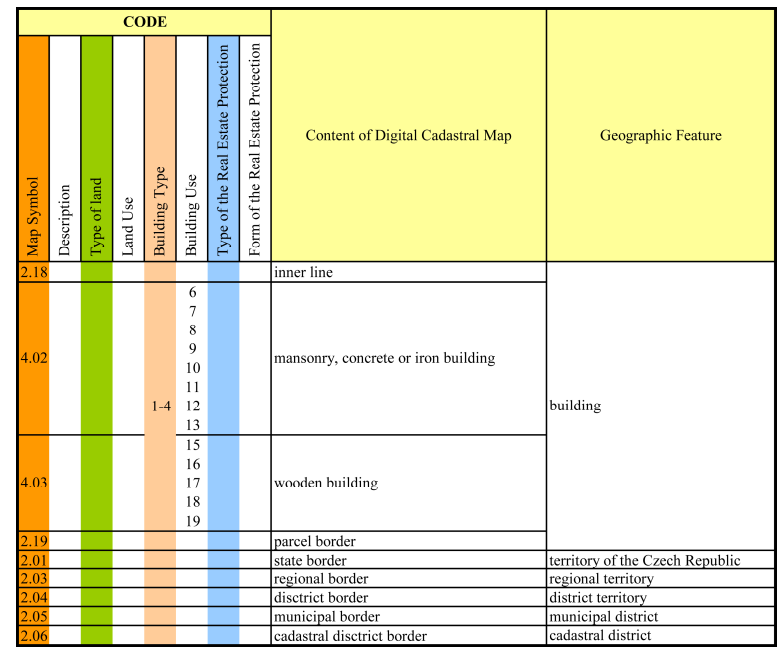

Figure 1. Examples of the content of digital cadastral map in the Czech Republic.

Reference data are defined by INSPIRE as series of datasets that everyone involved with geographic information uses to reference his/her own data as part of their work. It provides also a common link between applications and thereby provides a mechanism for the sharing of knowledge and information amongst people. Reference data must fulfil three functional requirements:

- provide a unique location for a user's information;

- $\quad$ enable the merging of data from various sources;

- provide a context to allow others to better understand the information that is being presented. (DPLI Working Group 2002)

The unavailability of reference data at land parcel data model in digital form covering the entire territory of the Czech Republic lead in 2008 to a decision to create a Digital map of public administration (DMVS). It should serve as reference data for public administration including spatial planning as well as Integrated Rescue System of the Czech Republic and Police of the Czech Republic.

\section{BASIC REGISTERS OF PUBLIC ADMINISTRATION}

The main aim of basic registers of public administration in the Czech Republic is to avoid duplication, fragmentation and obsolete information in databases. Similarly to the INSPIRE approach, all the databases' records must be shared between different sectors of public administration as reference data.

The system of basic registers defined in $\S 3$ of Act. No. $111 / 2009$ Coll. is composed of the following registers:

- Basic register of inhabitants, responsibility of the Ministry of Interior of the Czech Republic

- Basic register of persons, responsibility of the Czech Statistical Office

- Basic register of territorial identification, addresses and real estates (hereinafter referred to as RUIAN), responsibility of the Czech Office for Surveying, Mapping and Cadastre

- Basic register of rights and duties, responsibility of the Ministry of Interior of the Czech Republic.
Geographical features in RUIAN should be portrayed using state map series or digital map of public administration (DMVS).

\section{DIGITAL MAP OF PUBLIC ADMINISTRATION}

The Digital Map of Public Administration (hereinafter referred to as DMVS) should ensure guaranteed and unified digital vector maps as a reference data and their maintenance. Up-todate data of DMVS should serve to public administration, private sector and citizens. DMVS should therefore support the computerisation of spatial reference data of public administration.

The creation of the Digital map of public administration is anchored in the Memorandum of Cooperation between Ministry of Interior, Ministry of Environment, Ministry of Regional Development, Ministry of Agriculture, Czech Office for Surveying, Mapping and Cadastre, Union of Towns and Municipalities of the Czech Republic and Association of Regions of the Czech Republic in November 2008. The document states that spatial data needed for the performance of public administration do not exist in digital form in the entire territory of the Czech Republic. Therefore, it complicates the computerisation of public administration. The signatories of the Memorandum agreed that there is a need for quick solution of unavailability of spatial data and appointed Ministry of Interior to coordinate the DMVS project. DMVS is supported by funds from the Integrated Operational Programme (IOP).

A strategic target of the DMVS project is to secure unified reference digital map layer compliant with INSPIRE and covering the entire territory of the Czech Republic for the purposes of information systems of public administration.

From the technological point of view, DMVS should be composed of digital orthophotographs of the Czech Republic, existing digital cadastral maps and digitised cadastral maps, digital purpose cadastral map and digital technical maps if available (see Figure 2).

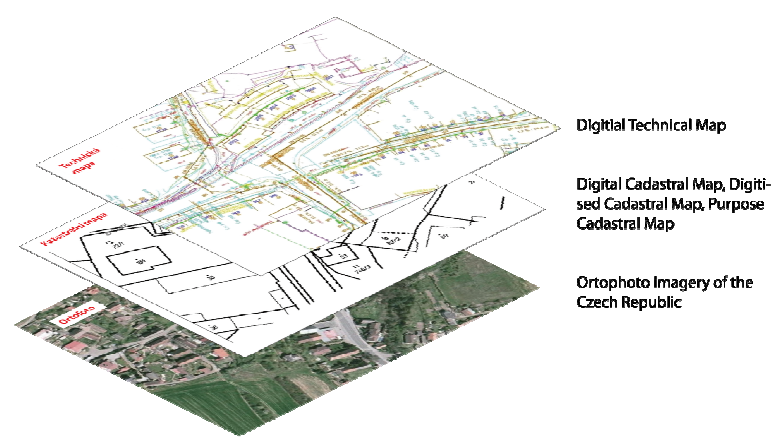

Figure 2. Digial Map of Public Administration (DMVS) and its components. (Source: http://www.mvcr.cz)

\subsection{Digital purpose cadastral map}

The basic characteristic of DMVS is the level of detail that should be equal to land parcel data model. State map series digital and digitised cadastral maps of the Czech Office for Surveying, Mapping and Cadastre should be the core for DMVS. This was also anchored in the Memorandum of Cooperation. Due to unavailability of digital cadastral maps in 
certain parts of the Czech Republic, it was decided to create a Digital purpose cadastral map (hereinafter referred to as UKM).

For the purposes of analytical studies, decision making processes and successful performance of public administration the digital purpose cadastral map (UKM) should:

- $\quad$ have unified qualitative, formal and content parameters;

- $\quad$ be acquired in short term period with minimal costs;

- contain property rights to land parcels;

- be continuously updated, i.e. to be compliant with cadastre of real estates;

- be created as a dataset that could secure the needs of public administration and citizens until the digital cadastral map covers the entire territory of a region.

According to the required functionality of UKM described in Ministry of Interior (2009), UKM should contain property rights to real estates.

Regions of the Czech Republic are responsible to apply for funds from Integrated Operational Programmes that should secure the management, fulfilment and maintenance of the DMVS project including UKM, digital technical map and planning analytical materials.

UKM is a basic component of DMVS and should meet the needs of public administration with the fact that UKM cannot be considered as a substitute for digital cadastral map from the legal point of view as it is noticed in Ministry of Interior (2009). Analogue cadastral maps available only on PET films should serve as reference layer for digitalisation of UKM. But these maps do not represent current positional and geometrical determination of real estates in accordance with valid regulations of the Czech Office for Surveying, Mapping and Cadastre. The selected technology for transformation of analogue maps into unified coordinate reference system JTSK is neither compliant with these regulations.

The process of creation of UKM guaranteed by regional authorities of the Czech Republic is being solved in parallel with digitalisation of cadastral maps. The government financially supported the digitalisation of cadastral maps that is guaranteed by the Czech Office for Surveying, Mapping and Cadastre. The digital cadastral map covering the entire territory of the Czech Republic should be finalised in 2015.

The process of creation of UKM is entirely dependent on a provision of cadastral maps as a state map series in large scale, maps of former land registries and the reference material which is in possession of Czech Office for Surveying, Mapping and Cadastre. Crucial part plays the role of Czech Office for Surveying, Mapping and Cadastre in the process of operative and rational update of created UKM. It is also necessary to temporally coordinate the digitalisation of cadastral map at the Czech Office for Surveying, Mapping and Cadastre with the creation of UKM at regional authorities to avoid duplication of processes.

\subsection{Digital technical map}

A Digital technical map (hereinafter referred to as DTM) is defined as a large scale map, maintained in digital form, displaying features from the Earth's surface and service infrastructure. The DTM should serve to citizens, service infrastructure managers, governmental bodies, Integrated
Rescue System of the Czech Republic, surveyors and architects as a reference data for public administration (e.g. spatial planning), an impulse for development of solutions based on GIS, a reference layer for portrayal of features from RUIAN, etc.

The DTM project is focused on creation of technical infrastructure in regions as a data storage for managing, providing and sharing of information between state administration, regional administration, local administration and managers of service infrastructures if all these involved subjects will decide to share the information. The DTM project does not take into account a systematic collection of datasets of technical map and its maintenance.

The aim of the DTM is to ensure effective management of DTM dataset including finances, processes, personnel and technology. Technological infrastructure of DTM should be ensured by technological centres of the regions. The DTM project assumes cooperation between regions, municipalities (public sector) and managers of transport and technical infrastructure (private sector). The regions should ensure realisation of the project and also maintenance of DTM. Other subjects involved should secure data collection and update. It is also expected their financial contribution for DTM management. The creation of DTM is no mandatory in the frame of the Call from Integrated Operational Programme.

\subsection{Planning analytical materials}

In the Czech Republic (2006) it is mentioned that planning analytical materials (hereinafter referred to as UAP) contain

- the ascertainment and assessment of the state and development of the area, its values, limitation of the changes in the area due to protection of public priorities, arising from the regulations or stipulated under the special regulations or arising from the properties of the area (hereinafter referred to as "limits of the area use"),

- programmes for executing the changes in the area,

- ascertaining and assessing the area sustainable development, and

- determination of problems for solution in the planning documentation (hereinafter referred to as UPD).

Planning analytical materials are procured by appropriate procurer upon the survey of the area and upon the data on the area, which are

- the information or data on the area condition, on rights, duties and limitations, which are bound to a certain part of the territory, for example, an area, a ground, a natural form or a structure, and which was created or ascertained especially based on regulations, and

- the information or data on the programmes to execute a change in the area.

Data on the area include also the information on their origin, creation, processing, a possible approval or coming into force and effect. As a material for procurement of the planning analytical materials may be also used a technical map. 
Map sets used for processing of UAP and UPD are cadastral map, State Map (SM5), Basic Map of the Czech Republic (ZM CR) and Map of the Czech Republic. These are all state map series. In case there is any inconsistency between these maps and the reality, the surveyors collect the update for the purposes of UAP and UPD. But these updates are not further used for the update of the state map series themselves.

The update of UAP is anchored in the Building Act (Czech Republic 2006). The producer of UAP is responsible for its update from various sources. The updates from various sources can be large and are heterogeneous and therefore use of IT technologies including GIS for data processing is supported.

The UAP project within the context of DMVS is taken as an add-on project focused on spatial planning. The aim of the UAP project is to make spatial planning data and metadata more accessible and to make the processes in spatial planning more effective. The sharing mechanisms including data specification should be compliant with the INSPIRE Directive. Remote access to data using web services is therefore essential. A geoportal solution for data, metadata and service sharing should enable search, viewing and download services.

Spatial planning is one of the most important areas that strongly influence social, political, economic and environmental issues on all levels. Sustainable planning addresses the environment where people live and work, the location of social and economic activities and the way in which the resources we possess are exploited. Spatial planning needs up-to-date, quality, accurate and reliable information generated by using up-to-date, quality, accurate and reliable reference datasets of geodata. Quality processed UAP and UPD play crucial role in these processes. It is necessary in the DMVS project to stress out the importance of cadastre data as a reference data for UAP and UPD.

\section{CONCLUSIONS}

A discussion between the main actors in the area of geodata in the Czech Republic resulted in signing the Memorandum of Cooperation on preparations, execution, realisation and testing of the DMVS project. This step triggered the computerisation of public administration and creation of national geoinformation infrastructure. The need for quality and up-to-date basic reference geodata at the parcel data model level was clearly formulated.

The current process of digitalisation of cadastral maps performed by the Czech Office for Surveying, Mapping and Cadastre, its management and maintenance does not meet the requirements of users of this map state series. The content of cadastral maps was reduced and the regular update of this valuable dataset was abandoned.

Cadastral map should ensure basic functionality of cadastre as defined in the Cadastral Act. The Cadastral Act says that cadastre is a source of information that serves as a protection of rights to real estates, for a tax purposes, for a protection of environment, agriculture and forestry, mineral resources and cultural monuments, for a development of territory, for a real estate valuation, for a scientific, economic and statistical purposes and for a creation of other information systems.
The amendment of the Act No. 200/1994 Coll., on Surveying and Mapping defines a term technical map of municipality. It was set that creation and maintenance of the technical map of municipality is an activity of surveyors performed for the public interests. The Czech Office for Surveying, Mapping and Cadastre should set the basic content of the technical map of municipality. The amendment of the Surveying and Mapping Act sets that the content of the technical map of municipalities should be standardised by municipalities. The Czech Office for Surveying, Mapping and Cadastre assumes that the harmonisation of the content of the technical map of municipalities will be later on compelled by the users of the technical map.

According to the INSPIRE principle that data should be collected once and maintained at the level where this can be done most effectively, it is questionable if the DMVS project is compliant with INSPIRE. Cadastral map, as a state map series in large scale, is guaranteed and managed by the Czech Office for Surveying, Mapping and Cadastre under the state budget (national level). Technical maps has been managed and financed by municipalities (local level). The DMVS project should be financed and managed from the regional authorities (regional level). The question is whether the regional level for administration of the DMVS datasets is sustainable and the most effective.

\section{REFERENCES}

Čada, V. 2007, Digitální katastrální mapy z pohledu funkce státního mapového díla (Digital Cadastral Maps from the Point of View of State Map Series). Kartografické listy,p. 25-33.

Čada, V. 2009, Účelová katastrální mapa v kontextu digitální mapy veřejné správy (Purpose Cadastral Map in the Context of Digital Map of Public Administration). Abstracts from Geomatika v projektech 2009.

Čada, V. \& Mildorf, T., 2005. Delimitation of reference geodata from land data model. Proceedings of GIS Ostrava 2005. Ostrava: VŠB - TUO.

Czech Republic 2005, Act No. 344/1992 Coll., on Cadastre of Real Estates of the Czech Republic (Cadastral Law) in wording of later regulations.

Czech Republic 2005a, Act No. 200/1994 Coll., on Surveying and Mapping and on Changes and Amendments of some Acts in connection with its coming into force in wording of later regulations.

Czech Republic 2006, Act No. 183/2006 Coll., on town and country planning and building code (Building Act).

Czech Republic 2009, Act No. 111/2009 Coll., on basic registers.

Czech Republic 2006, Decree No. 500/2006 Coll., on planning analytical materials, planning documentation and methods for filing town planning activities.

Czech Republic 2007, Decree No.26/2007 Coll., of the Czech Office for Surveying, Mapping and Cadastre performing the Act No.265/1992 Coll., on Registration of Proprietary and other Material Rights to Real Estates in wording of later regulations and the Act No. 344/1992 Coll., on Cadastre of Real Estates of 
the Czech Republic (Cadastral Law) in wording of later regulations.

DPLI Working Group, 2002. Data Policy \& Legal Issues Position Paper. http://inspire.jrc.ec.europa.eu/reports/position_papers/inspire_d pli_pp_v12_2_en.pdf (accessed 15 October 2010)

European Parliament 2007. INSPIRE Directive 2007 Directive 2007/2/EC of the European Parliament and of the Council of 14 March 2007 establishing an Infrastructure for Spatial Information in the European Community (INSPIRE), http://inspire.jrc.ec.europa.eu/

International Organization for Standardization 2004. ISO 19125 - Geographic information - Simple Feature Access.

Kubatova, E. 2009, Projekt Digitální mapa veřejné správy (The

Digital Map of Public Administration Project), http://www.mvcr.cz/clanek/digitalni-mapa-verejne-

spravy.aspx?q=Y2hudW09Mg\%3d\%3d (accessed 15 October 2010).

Memorandum o spolupráci mezi Ministerstvem vnitra ČR, Ministerstvem životního prostředí ČR, Ministerstvem pro místní rozvoj ČR, Ministerstvem zemědělství ČR, Českým úřadem zeměměřickým a katastrálním, Svazem měst a obcí ČR a Asociací krajů ČR při přípravě, řešení, realizaci a testování projektu „Digitální mapa veřejné správy“ (Memorandum of Cooperation on Digital Map of Public administration). Praha 2008.

Ministry of Interior 2009, "Účelová katastrální mapa typizovaný projektový záměr (Purpose Cadastral Map), version 1.4 (18.9. 2009)", Ministry of Interior of the Czech Republic. URL: $\quad$ http://www.osf-mvcr.cz/vyzvy/2-1-zavadeni-ict-vuzemni-verejne-sprave-leden-2010 (accessed 15 October 2010)

Ministry of Interior 2009a, "Digitální technická mapa typizovaný projektový záměr, version 1.1 (18.9. 2009) (Digital Technical Map)". Ministry of Interior of the Czech Republic. URL: $\quad$ http://www.osf-mvcr.cz/vyzvy/2-1-zavadeni-ict-vuzemni-verejne-sprave-leden-2010 (accessed 15 October 2010)

Ministry of Interior 2009b, "Nástroje pro tvorbu a údržbu územně analytických podkladů - typizovaný projektový záměr, version 1.1 (18.9. 2009) (Tools for Creation and Maintenance of Planning Analytical Materials)". Ministry of Interior of the Czech Republic. URL: http://www.osf-mvcr.cz/vyzvy/2-1zavadeni-ict-v-uzemni-verejne-sprave-leden-2010 (accessed 15 October 2010)

\section{ACKNOWLEDGEMENTS}

The author V. Cada is supported by the Research Plan MSM 4977751301.

The author T. Mildorf is supported by the Plan4all project, cufunded by the eContent plus programme of the European Commission. 
International Archives of the Photogrammetry, Remote Sensing and Spatial Information Sciences, Volume XXXVIII-4/C21 